\title{
$\left.{ }^{125} \mathrm{I}\right]-\mathrm{S36057}$ : a new and highly potent radioligand for the melanin-concentrating hormone receptor
}

\author{
${ }^{1}$ Valérie Audinot, ${ }^{1}$ Chantal Lahaye, ${ }^{1}$ Thomas Suply, ' Philippe Beauverger, ${ }^{1}$ Marianne Rodriguez, \\ ${ }^{1}$ Jean-Pierre Galizzi, ${ }^{2}$ Jean-Luc Fauchère \& *,1 Jean A. Boutin
}

${ }^{1}$ Division de Pharmacologie Moléculaire et Cellulaire, Institut de Recherches Servier, 125 chemin de Ronde, 78290 Croissy sur Seine, France and ${ }^{2}$ Division des Peptides et de Chimie Combinatoire, Institut de Recherches Servier, 11, rue des Moulineaux, 92150 Suresnes, France

1 Shortened, more stable and weakly hydrophobic analogues of melanin-concentrating hormone $(\mathrm{MCH})$ were searched as candidates for radioiodination. Starting from the dodecapeptide $\mathrm{MCH}_{6-17}$, we found that: (1) substitution of $\mathrm{Tyr}^{13}$ by a Phe residue; (2) addition of a 3-iodo-Tyr residue at the $\mathrm{N}$ terminus; and (3) addition of a hydrophilic spacer 8-amino-3,6-dioxyoctanoyl between the 3-iodo-Tyr and $\mathrm{MCH}_{6-17}$ (compound $\mathrm{S} 36057$ ), led to an agonist more potent than $\mathrm{MCH}$ itself in stimulating $\left.{ }^{35} \mathrm{~S}\right]-$ $\mathrm{GTP} \gamma \mathrm{S}$ binding at membranes from HEK293 cells stably expressing the human $\mathrm{MCH}$ receptor.

2 Specific binding of $\left[{ }^{125} \mathrm{I}\right]-\mathrm{S} 36057$ was found in HEK293 and CHO cell lines stably expressing the human $\mathrm{MCH}$ receptor. This radioligand recognized a similar number of binding sites ( $c a$. $800 \mathrm{fmol} \mathrm{mg}^{-1}$ ) than $\left.{ }^{125} \mathrm{I}\right]-\left[3\right.$-iodo $\left.\mathrm{Tyr}^{13}\right]-\mathrm{MCH}$.

3 However, the $K_{D}$ for $\left[{ }^{125} \mathrm{I}\right]-\mathrm{S} 36057$ obtained from saturation studies $(0.037 \mathrm{nM})$ or from binding kinetics $(0.046 \mathrm{nM})$ was at least 10 fold higher to that of $\left[{ }^{125} \mathrm{I}\right]$-[3-iodo $\left.\mathrm{Tyr}^{13}\right]-\mathrm{MCH}(0.46 \mathrm{nM})$.

4 Affinities determined for a series of $\mathrm{MCH}$ analogues were similar with both radioligands, S36057 being the most potent compound tested $\left(K_{\mathrm{i}}=0.053 \mathrm{nM}\right)$.

5 Finally, $\left[{ }^{125} \mathrm{I}\right]-\mathrm{S} 36057$ also potently labelled the $\mathrm{MCH}$ receptor in membranes from whole rat brain $\left(K_{D} 0.044 \mathrm{nM}, \mathrm{B}_{\max }=11 \mathrm{fmol} \mathrm{mg}^{-1}\right)$.

6 In conclusion, $\left[{ }^{125} \mathrm{I}\right]-\mathrm{S} 36057$ is a more potent and more stable radioligand than $\left[{ }^{125} \mathrm{I}\right]-[3$-iodo $\mathrm{Tyr}^{13}$ ]-MCH that will represent a reliable tool for binding assays in the search of novel $\mathrm{MCH}$ ligands. It should also provide great help for autoradiographic studies of the $\mathrm{MCH}$ receptor distribution in the central nervous system.

British Journal of Pharmacology (2001) 133, 371-378

Keywords: [ $\left.{ }^{125} \mathrm{I}\right]-\left(3\right.$-iodo $\left.\mathrm{Tyr}^{13}\right)-\mathrm{MCH}$ binding; [ $\left.{ }^{125} \mathrm{I}\right]-\mathrm{S} 36057$ binding; $\mathrm{MCH}$; SLC-1 receptor

Abbreviations: CHO, Chinese hamster ovary; $\left[{ }^{35} \mathrm{~S}\right]-\mathrm{GTP} \gamma \mathrm{S}$, guanosine-5'-O-(3-[ $\left.{ }^{35} \mathrm{~S}\right]$-thio-triphosphate); HEK, human embryonic kidney; $\mathrm{MCH}$, melanin concentrating hormone (human, rat, mouse); SLC-1, somatostatin-like receptor 1

\section{Introduction}

Human melanin-concentrating hormone $(\mathrm{MCH})$ is a cyclic nonadecapeptide, involved in the regulation of feeding behaviour (Qu et al., 1996; Presse et al., 1996; Rossi et al., 1997; Tritos \& Maratos-Flier, 1999; Shimada et al., 1998). While $\mathrm{MCH}$ has been known for a long time (Kawauchi et al., 1983), its receptor has been cloned only recently by reverse pharmacology (Chambers et al., 1999; Saito et al., 1999; Shimomura et al., 1999; Bachner et al., 1999; Lembo et al., 1999, for review see Saito et al., 2000). The $\mathrm{MCH}$ function was assigned to the orphan receptor SLC-1 (Kolakowski et al., 1996; Lakaye et al., 1998), on the basis of the observed inhibition of forskolin-stimulated cyclic AMP production and induction of calcium rise. Indeed, the lack of suitable binding conditions, due mainly to the hydrophobic and sticky nature of $\mathrm{MCH}$ (Drozdz \& Eberle, 1995a; Kokkotou et al., 2000), was a limiting step for expression cloning. Now that the receptor has been cloned, the distribution of receptor mRNA in the central nervous system has been characterized precisely (Hervieu et

*Author for correspondence; E-mail: jean.boutin@fr.netgrs.com al., 2000). However no autoradiographic studies showing the distribution of the receptor protein are yet available. In the past, several attempts failed to find either a tritiated or an iodinated (Drozdz \& Eberle, 1995a; Hintermann et al., 1999) potent and stable ligand, although the iodinated analogue $\left[{ }^{125} \mathrm{I}\right]-\left[\mathrm{Phe}^{13} \mathrm{Tyr}^{19}\right]-\mathrm{MCH}$ was shown to detect a potential $\mathrm{MCH}$ site in several cell lines and tissues (Drozdz \& Eberle, 1995b; Burgaud et al., 1997). However, comparison of the functional and binding data obtained at the recently cloned receptor, with those previously reported in native cell lines, showed that the latter $\mathrm{MCH}$ binding sites did not match those at the cloned $\mathrm{MCH}$ receptor (Drozdz \& Eberle, 1995a; Drozdz et al., 1995; Burgaud et al., 1997; Chambers et al., 1999; Lembo et al., 1999). Therefore, the results obtained in these studies, including the $\mathrm{MCH}$ structure-activity relationships, should be interpreted cautiously (Drozdz \& Eberle, 1995a; Drozdz et al., 1995). Iodination of the residue $\mathrm{Tyr}^{13}$, inside the Cys-Cys loop, of human $\mathrm{MCH}$ has been achieved recently and three groups have reported limited binding data at both cloned and native human $\mathrm{MCH}$ receptors (Chambers et al., 1999; Sone et al., 2000; Macdonald et al., 2000). 
However, the sticky nature of $\mathrm{MCH}$ and its sensitivity to proteolysis (Checler et al., 1992; Castrucci et al., 1992; Hintermann et al., 1999; Kokkotou et al., 2000), required the discovery of a shorter, more stable radiolabelled and potentially less hydrophobic ligand.

In a recent and extensive study characterizing $57 \mathrm{MCH}$ analogues for their functional activity at the human cloned $\mathrm{MCH}$ receptor to inhibit cyclic AMP formation or alternatively to stimulate $\left[{ }^{35} \mathrm{~S}\right]-\mathrm{GTP} \gamma \mathrm{S}$ binding, we have shown that the minimal sequence required for a potent $\mathrm{MCH}$ agonist activity was the dodecapeptide $\mathrm{MCH}_{6-17}$ (Audinot et al., 2001). In the present study, analogues of this peptide were investigated as candidates for iodination. The agonist activity at the human $\mathrm{MCH}$ receptor was evaluated through two functional assays: the inhibition of forskolin-stimulated cyclic AMP level and the stimulation of $\left[{ }^{35} \mathrm{~S}\right]-\mathrm{GTP} \gamma \mathrm{S}$ binding. The strategy involved the substitution of $\mathrm{Tyr}^{13}$ by a Phe residue and the addition of a 3-iodo-Tyr residue at the $\mathrm{N}$-terminal position which was linked to $\mathrm{Arg}^{6}$ via a relatively hydrophilic spacer (dioxyoctanoyl) leading to compound S36057. The characterization of $\left[{ }^{125} \mathrm{I}\right]-\mathrm{S} 3605$ binding was compared with that of $\left.{ }^{[25} \mathrm{I}\right]$-(3-iodo $\left.\mathrm{Tyr}^{13}\right)-\mathrm{MCH}$ at the human cloned receptor as well as in rat brain membranes.

\section{Methods}

\section{Peptides}

Most of the natural and modified peptides were customsynthesized from Neosystem, Strasbourg, France, and checked by HPLC and mass spectrometry. Analytical data of the peptides are given in Table 1 .

\section{Iodination of $\left[{ }^{125} \mathrm{I}\right]-\mathrm{S} 36057$}

$\mathrm{S} 36057\left(50 \mu \mathrm{g} ; 1.0 \mathrm{mg} \mathrm{ml}^{-1}\right)$ in phosphate buffer $(0.2 \mathrm{M}$; pH 7.4; $300 \mu \mathrm{l})$ in an Eppendorf tube was mixed with sodium [ $\left.{ }^{125} \mathrm{I}\right]$-iodide (IMS30; $249 \mathrm{MBq} ; 7 \mathrm{mCi} ; 70 \mu \mathrm{l}$; Amersham Pharmacia Biotech, England). Reaction was initiated by addition of lactoperoxidase $\left(25 \mathrm{IU} \mathrm{ml}^{-1} ; 50 \mu \mathrm{l}\right)$ and hydrogen peroxide $(0.003 \% ; 50 \mu \mathrm{l})$ and allowed to react for $20 \mathrm{~min}$. The reaction mixture was loaded onto a Jupiter C-5 RPHPLC column $(250 \times 4.6 \mathrm{~mm}$; Phenomenex, U.K. $)$ and purified to obtain the mono-iodinated product (74 $\mathrm{TBq} \mathrm{mmol}^{-1}, 2000 \mathrm{Ci} \mathrm{mmol}^{-1}$ ) using a linear gradient with water, acetonitrile and trifluoracetic acid. The product was diluted with a sodium phosphate $(50 \mathrm{~mm}$; pH 7.4), lactose $(5 \%)$, bovine serum albumin $(0.25 \%$; RIA grade), Lmethionine $(0.1 \%)$ and aprotinin $\left(0.3 \mathrm{TIU} \mathrm{ml}^{-1}\right)$ buffer to obtain $100 \mu \mathrm{Ci} \mathrm{ml})^{-1}$ in the buffer. The product was freezedried overnight and stored at $4{ }^{\circ} \mathrm{C}$.

\section{Establishment of stable cell lines}

HEK293 (HEK) or CHO cells grown in DMEM medium supplemented with $10 \%$ foetal calf serum, $2 \mathrm{~mm}$ glutamine, $100 \mathrm{IU} \mathrm{ml} \mathrm{m}^{-1}$ penicillin and $100 \mu \mathrm{g} \mathrm{ml}^{-1}$ streptomycin were seeded at $5 \times 10^{6}$ cells in a $\mathrm{T} 75 \mathrm{~cm}^{2}$ culture flask. Twentyfour hours later, they were transfected with $10 \mu \mathrm{g}$ of the pcDNA3.1 (Invitrogen, Groningen, The Netherlands) containing the human $\mathrm{MCH}$ receptor using lipofectamine (Life Technologies, Cergy Pontoise, France) as previously described (Audinot et al., 2001). The day following transfection, cells were trypsinized, resuspended in complete DMEM medium containing $800 \mu \mathrm{g} \mathrm{ml}^{-1}$ of active geneticin and seeded at different dilutions in 96-well plates which were kept 2-3 weeks in a humidified $\mathrm{CO}_{2}$ incubator. At

Table 1 Analytical data of the peptides

\begin{tabular}{|c|c|c|c|c|c|}
\hline Compound & Structure & $\begin{array}{c}r_{t} \\
(\min )^{\mathrm{a}}\end{array}$ & $\begin{array}{c}\text { Counterion/ } \\
\text { gradient } \\
\text { type }^{\mathrm{b}}\end{array}$ & $M(\mathrm{ES})^{\mathrm{c}}$ & $\begin{array}{l}\text { Purity \% } \\
\text { (HPLC) }^{\mathrm{d}}\end{array}$ \\
\hline Rat, human $\mathrm{MCH}^{*}$ & $\begin{array}{l}\text { Asp-Phe-Asp-Met-Leu-Arg-Cys-Met-Leu-Gly-Arg-Val-Tyr-Arg-Pro-Cys-Trp- } \\
\text { Gln-Val }\end{array}$ & 17.37 & TFA(1) & 2387.1 & 96.5 \\
\hline Salmon $\mathrm{MCH}^{*}$ & Asp-Thr-Met-Arg-Cys-Met-Val-Gly-Arg-Val-Tyr-Arg-Pro-Cys-Trp-Glu-Val & 18.04 & TEAP(2) & 2099.3 & 97.3 \\
\hline$\left[\mathrm{Phe}^{13}, \mathrm{Tyr}^{19}\right]-\mathrm{MCH}^{*}$ & $\begin{array}{l}\text { Asp-Phe-Asp-Met-Leu-Arg-Cys-Met-Leu-Gly-Arg-Val-Phe-Arg-Pro-Cys-Trp- } \\
\text { Gln-Tyr }\end{array}$ & 17.94 & TFA(1) & 2434.7 & 95.1 \\
\hline (3-iodo $\left.\mathrm{Tyr}^{13}\right)-\mathrm{MCH}$ & $\begin{array}{c}\text { Asp-Phe-Asp-Met-Leu-Arg-Cys-Met-Leu-Gly-Arg-Val-(I)Tyre-Arg-Pro-Cys- } \\
\text { Trp-Gln-Val }\end{array}$ & 11.91 & TEAP(3) & 2512.7 & 95.8 \\
\hline $\mathrm{MCH}_{6-17}$ & Arg-Cys-Met-Leu-Gly-Arg-Val-Tyr-Arg-Pro-Cys-Trp & 18.97 & TFA(2) & 1537.7 & 95.0 \\
\hline Compound 1 & Tyr-Gly-Gly-Arg-Cys-Met-Leu-Gly-Arg-Val-Tyr-Arg-Pro-Cys-Trp & 14.93 & TEAP(2) & 1814.8 & 95.2 \\
\hline Compound 2 & (I)Tyr-Gly-Gly-Arg-Cys-Met-Leu-Gly-Arg-Val-Tyr-Arg-Pro-Cys-Trp & 13.35 & TFA(1) & 1941.0 & 96.7 \\
\hline Compound 3 & Tyr-Gly-Gly-Arg-Cys-Met-Leu-Gly-Arg-Val-Phe-Arg-Pro-Cys-Trp & 13.74 & TFA(1) & 1799.2 & 97.2 \\
\hline Compound 4 & (I)Tyr-Gly-Gly-Arg-Cys-Met-Leu-Gly-Arg-Val-Phe-Arg-Pro-Cys-Trp & 14.51 & TFA(2) & 1925.1 & 97.4 \\
\hline Compound 5 & Tyr-ADO ${ }^{f}$-Arg-Cys-Met-Leu-Gly-Arg-Val-Phe-Arg-Pro-Cys-Trp & 14.08 & TFA(2) & 1830.5 & 98.6 \\
\hline S36057 & (I)Tyr-ADOf-Arg-Cys-Met-Leu-Gly-Arg-Val-Phe-Arg-Pro-Cys-Trp & 15.41 & TFA(2) & 1956.4 & 97.8 \\
\hline S36077 & Arg-Ser-Met-Leu-Gly-Arg-Val-Tyr-Arg-Pro-Ser-Trp & 13.00 & TFA(2) & 1508.2 & 95.4 \\
\hline S36541 & Gua-Cys-Nle-Leu-Gly-Arg-Nva-Tyr-Arg-Acp-Asp-Bta ${ }^{g}$ & 18.16 & TEAP(1) & 1555.6 & 93.1 \\
\hline S36539 & Gua-Dab-Nle-Leu-Gly-Arg-Nva-Tyr-Arg-Acp-Asp-Bta ${ }^{g}$ & 17.04 & TEAP(1) & 1562.6 & 97.1 \\
\hline S36540 & Gua-Dap-Nle-Leu-Gly-Arg-Nva-Tyr-Arg-Acp-Asp-Bta ${ }^{g}$ & 16.60 & TEAP(1) & 1534.6 & 96.1 \\
\hline \multicolumn{6}{|c|}{ 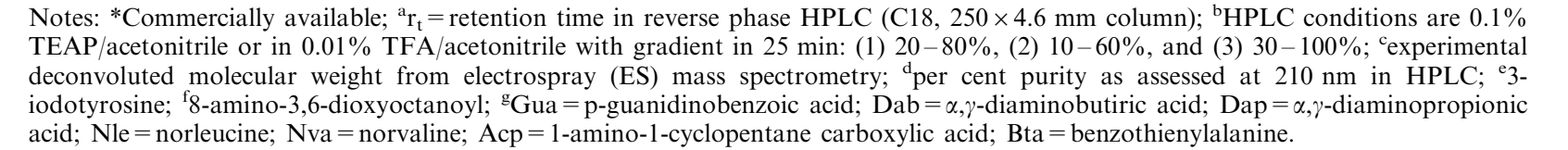 } \\
\hline
\end{tabular}


the end of this selection period, isolated clones were picked, amplified and further characterized by cyclic AMP experiments. For each cell line, one positive clone was subcloned before being used for all the cyclic AMP, $\left[{ }^{35} \mathrm{~S}\right]-$ GTP $\gamma \mathrm{S}$ and receptor binding experiments. The stable HEK293 and $\mathrm{CHO}$ cell lines expressing the human $\mathrm{MCH}$ receptor were, respectively, named HEK-hMCH-R and CHO-hMCH-R.

\section{Intracellular cyclic AMP assay}

Intracellular cyclic AMP was determined using the Flashplate technology (SMP004 New England Nuclear, Les Ulis, France). Briefly, forskolin $(15 \mu \mathrm{M})$ and test peptides diluted in $0.1 \%$ BSA were added into 96-well flashplates and incubation was started with the addition of HEK-hMCH-R cells stably expressing the human or rat $\mathrm{MCH}$ receptor $\left(35,000\right.$ cells per well). After $15 \mathrm{~min}$ at $37^{\circ} \mathrm{C}$, incubation was stopped by the addition of the revelation mix and $2 \mathrm{~h}$ later, plates were counted on a TopCount (Packard, Meriden, CT, U.S.A.).

\section{Membrane preparations of cell lines}

Cell lines stably expressing the human $\mathrm{MCH}$ receptor were grown to confluency, harvested in PBS buffer containing $2 \mathrm{mM}$ EDTA and centrifuged at $1000 \times \mathrm{g}$ for $5 \mathrm{~min}\left(4^{\circ} \mathrm{C}\right)$. The resulting pellet was suspended in $20 \mathrm{mM}$ HEPES buffer (pH 7.5), containing $5 \mathrm{~mm}$ EGTA and homogenized using a Kinematica polytron. The homogenate was then centrifuged $\left(95,000 \times \mathrm{g}, 30 \mathrm{~min}, 4^{\circ} \mathrm{C}\right)$ and the resulting pellet suspended in $50 \mathrm{~mm}$ HEPES buffer ( $\mathrm{pH} 7.5$ ), containing $10 \mathrm{mM} \mathrm{MgCl}_{2}$ and $2 \mathrm{mM}$ EGTA. Aliquots of membrane preparations were stored at $-80^{\circ} \mathrm{C}$ until use.

\section{Rat brain membrane preparation}

Frozen whole rat brains (Iffa Credo, L'Arbresle, France) were suspended using a Kinematica polytron in $50 \mathrm{~mm}$ TRIS buffer ( $\mathrm{pH} 7.4$ ), containing (in $\mathrm{mM}$ ): $\mathrm{NaCl} 120, \mathrm{KCl}$ 5, $\mathrm{MgCl}_{2} 1$ and $\mathrm{CaCl}_{2}$ 2.5. The suspension was centrifuged for $15 \mathrm{~min}$ at $50,000 \times \mathrm{g}$. The resulting pellet was resuspended in the same buffer and centrifuged again. Aliquots of membrane preparations were stored at $-80^{\circ} \mathrm{C}$ until use.

\section{$\left[{ }^{35} S\right]-G T P \gamma S$ binding}

Membranes and peptides were diluted in $50 \mathrm{~mm}$ HEPES buffer (pH 7.4), containing $100 \mathrm{mM} \mathrm{NaCl}, 3 \mu \mathrm{M}$ GDP, $5 \mathrm{mM} \mathrm{MgCl}_{2}, \quad 0.1 \%$ BSA, and $10 \mu \mathrm{g} \mathrm{ml}^{-1}$ saponin. Incubation was started by the addition of $0.2 \mathrm{nM}\left[{ }^{35} \mathrm{~S}\right]-$ GTP $\gamma \mathrm{S} \quad\left(1000 \mathrm{Ci} \mathrm{mmol}^{-1}\right.$, Amersham Pharmacia Biotech, Orsay, France) to membranes $\left(25 \mu \mathrm{g} \mathrm{ml}^{-1}\right)$ and test compounds, and continued for $45 \mathrm{~min}$ at room temperature. Non-specific binding was defined using nonradiolabelled $\operatorname{GTP} \gamma \mathrm{S}(10 \mu \mathrm{M})$. Reaction was stopped by rapid filtration through $\mathrm{GF} / \mathrm{B}$ unfilters followed by three successive washes with ice cold buffer. Data were analysed by non-linear regression using the program Prism (GraphPad Software Inc., San Diego, CA, U.S.A.), to yield $\mathrm{EC}_{50}$ (Effective Concentration ${ }_{50}$ ).

\section{$\left[{ }^{125} I\right]$-(3-iodo $\left.T y r^{13}\right) M C H$ and $\left[{ }^{125} I\right]-S 36057$ binding}

Cell lines membranes $\left(10-25 \mu \mathrm{g} \mathrm{m}^{-1}\right)$ or rat brain membranes $\left(50 \mu \mathrm{g} \mathrm{ml}^{-1}\right)$ were incubated for $90 \mathrm{~min}$ at room temperature in $25 \mathrm{mM}$ HEPES buffer ( $\mathrm{pH}$ 7.4), containing $1 \mathrm{mM} \mathrm{CaCl}, 5 \mathrm{mM} \mathrm{MgCl}, 0.5 \% \mathrm{BSA}$, in a final volume of $250 \mu \mathrm{l}$ containing, except where stated otherwise, $0.02 \mathrm{nM}$ of [ $\left.{ }^{125} \mathrm{I}\right]-\left(3\right.$-iodo $\left.\mathrm{Tyr}^{13}\right)-\mathrm{MCH}\left(2000 \mathrm{Ci} \mathrm{mmol}^{-1}\right.$, NEN, Les Ulis, France) or $\left.{ }^{[25} \mathrm{I}\right]-\mathrm{S} 36057$ (vide supra, $2000 \mathrm{Ci} \mathrm{mmol}^{-1}$ ) and test peptides. Non-specific binding was defined with $1 \mu \mathrm{M}$ $\mathrm{MCH}$. The reaction was stopped by rapid filtration through $\mathrm{GF} / \mathrm{B}$ unifilters presoaked with polyethyleneimine $0.5 \%$, followed by three successive washes with ice cold buffer. Data were analysed by non-linear regression using the program Prism. For displacement experiments, inhibition constants $\left(K_{\mathrm{i}}\right)$ were calculated according to the Cheng-Prusoff equation: $K_{\mathrm{i}}=\mathrm{IC}_{50} /\left[1+\left(\mathrm{L} / K_{D}\right)\right]$, where $\mathrm{IC}_{50}$ is the Inhibitory Concentration $_{50}, \quad \mathrm{~L}$ is the concentration and $K_{D}$ the dissociation constant of the radioligand.

\section{Results}

\section{Design of a shortened iodinated MCH analogue}

In both tests performed on human $\mathrm{MCH}$ receptors expressed in HEK293 cells (HEK-hMCH-R), $\mathrm{MCH}_{6-17}$ was less potent than MCH: by ca. 10 fold in the cyclic AMP assay and only by 2 fold in the $\left.{ }^{35} \mathrm{~S}\right]-\mathrm{GTP} \gamma \mathrm{S}$ binding assay (Table 2, Figure 1). However, addition of a terminal Tyr residue in position 5 , bearing (compounds 2, 4 and S36057) or not (compounds 1, 3 and 5) an iodo group restored or even increased potencies as compared to $\mathrm{MCH}_{6-17}$ in both tests (Table 2). Substitution of $\mathrm{Tyr}^{13}$ by a Phe residue did not significantly alter the potency (compounds 3, 4, 5 and S36057). Addition of different spacers: Gly-Gly (compounds 1, 2, 3 and 4), 8amino-3,6-dioxyoctanoyl (ADO, compounds 5 and S36057) between a N-terminal tyrosine and $\mathrm{MCH}_{6-17}$ did not strongly alter the activity (Table 2). The final choice of the

Table 2 Functional potencies of $\mathrm{MCH}$ analogues to inhibit forskolin-induced cyclic AMP level in HEK-hMCH-R cells or to stimulate $\left[{ }^{35} \mathrm{~S}\right]-\mathrm{GTP} \gamma \mathrm{S}$ binding to membranes from HEK-hMCH-R cells

\begin{tabular}{lcc}
\hline & $\begin{array}{c}\text { cyclic AMP } \\
I C_{50} \pm \text { s.e.mean } \\
\text { Compound }\end{array}$ & $\begin{array}{c}\left.{ }^{35} S\right]-G T P \gamma S \\
E C_{50} \pm \text { s.e.mean } \\
(\mathrm{nm})\end{array}$ \\
$\mathrm{MCH}$ & $0.28 \pm 0.06^{*}$ & $6.7 \pm 0.9^{*}$ \\
$\mathrm{MCH}_{6-17}$ & $3.44 \pm 1.05^{*}$ & $14 \pm 2^{*}$ \\
Compound 1 & $0.48 \pm 0.16$ & $4 \pm 0.6$ \\
Compound 2 & $0.27 \pm 0.05$ & $4.0 \pm 1.2$ \\
Compound 3 & $1.03 \pm 0.39$ & $7.7 \pm 1.2$ \\
Compound 4 & $0.48 \pm 0.06$ & $6.7 \pm 1.3$ \\
Compound 5 & $0.39 \pm 0.10$ & $3.2 \pm 0.9$ \\
S36057 & $0.59 \pm 0.21$ & $2.1 \pm 0.8$
\end{tabular}

$\mathrm{IC}_{50}$ represents the concentration of peptide inducing $50 \%$ of inhibition of forskolin-induced cyclic AMP level. $\mathrm{EC}_{50}$ represents the concentration of peptide inducing $50 \%$ of the maximal effect on $\left[{ }^{35} \mathrm{~S}\right]-\mathrm{GTP} \gamma \mathrm{S}$ binding. Data represent the mean \pm s.e.mean of at least three separate experiments performed in triplicate determinations. *Data from Audinot et al. (2001). 
candidate for radioiodination was for compound 5 which was more potent than $\mathrm{MCH}$ at least in the $\left[{ }^{35} \mathrm{~S}\right]-\mathrm{GTP} \gamma \mathrm{S}$ binding assay (Table 2, Figure 1). Interestingly, S36057 was more stable towards proteolysis than $\mathrm{MCH}$, in protease-rich media (M. Bertrand, 2001, personal communication).

\section{[ $\left.{ }^{125} \mathrm{I}\right]-S 36057$ selectively binds to the human $\mathrm{MCH}$ receptor}

The ability of $\left[{ }^{125} \mathrm{I}\right]-\mathrm{S} 36057(0.02 \mathrm{nM})$ to selectively label the $\mathrm{MCH}$ receptor expressed either in HEK or CHO cells $(\mathrm{CHO}-$ hMCH-R) was evaluated (Figure 2). A saturable protein dose-dependent binding was observed in both transfected cell lines with a similar plateau, which may be indicative of a similar number of sites in both preparations. In contrast, no specific binding was observed on membranes from the

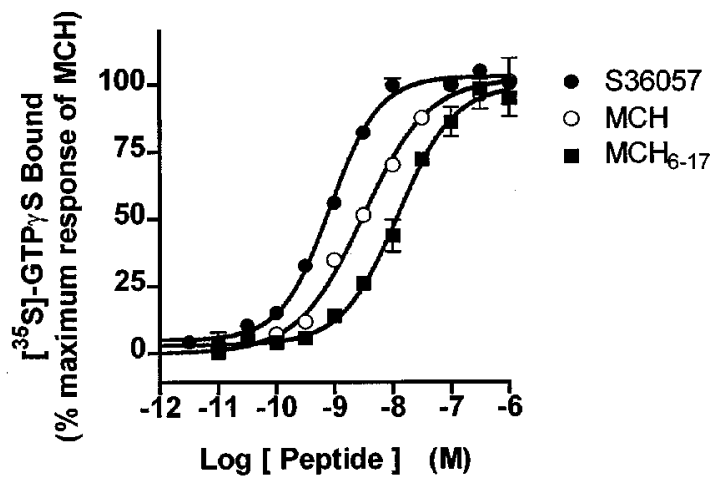

Figure 1 Dose-dependent stimulation of $\left[{ }^{35} \mathrm{~S}\right]-\mathrm{GTP} \gamma \mathrm{S}$ binding by S36057, MCH or $\mathrm{MCH}_{6-17}$ to HEK-hMCH-R membranes. Results are expressed as percentage of effect versus the maximal effect of $\mathrm{MCH} 1 \mu \mathrm{M} \quad(=100 \%)$. Basal binding level corresponded to $2736 \pm 180$ d.p.m. and the $\mathrm{MCH}$ maximal response $(1 \mu \mathrm{M})$ to $11750 \pm 936$ d.p.m. (corresponding to a 4.3 fold stimulation above basal). Points shown are from representative experiments performed in triplicates and repeated at least three times.

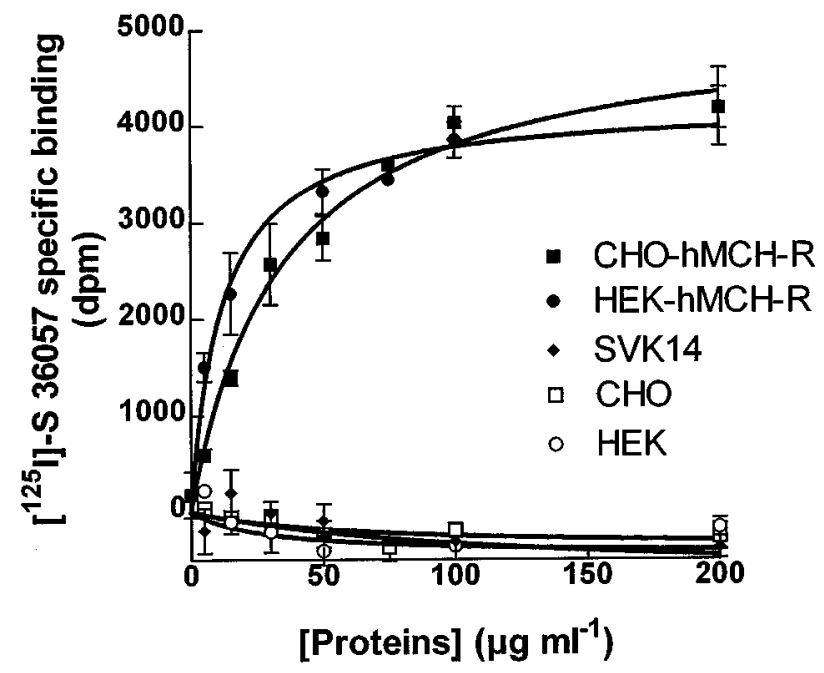

Figure 2 Specific binding of $\left[{ }^{125} \mathrm{I}\right]-\mathrm{S} 36057$ (0.02 nM) to membranes from HEK-hMCH-R or CHO-hMCH-R cells stably transfected with the human SLC-1 receptors, and from native HEK, CHO and SVK14 cells. The protein concentrations tested ranged from 0 to $200 \mu \mathrm{g} / \mathrm{ml}$. corresponding native cells nor from the SVK14 cell line, even at a high membrane concentration (Figure 2). Similar observations were made with $\left[{ }^{125} \mathrm{I}\right]-\left(3\right.$-iodo $\left.\mathrm{Tyr}^{13}\right)-\mathrm{MCH}$ (not shown). Specific binding represented typically $70-75 \%$ of total binding for both radioligands for a protein concentration of $10-25 \mu \mathrm{g} \mathrm{ml}^{-1}$, which was then routinely used.

Saturation studies: $\left[{ }^{125}\right.$ I]-S36057 is a highly potent radioligand

As shown in Figure 3 and in Table 3, $\left[{ }^{125} \mathrm{I}\right]-\mathrm{S} 36057$ and $\left[{ }^{125} \mathrm{I}\right]-$ (3-iodo $\mathrm{Tyr}^{13}$ )-MCH labelled a similar number of sites at HEK-hMCH-R membranes. However, when comparing the $K_{D}$ values $\left[{ }^{125} \mathrm{I}\right]-\mathrm{S} 36057$ was a more potent radioligand than $\left[{ }^{125} \mathrm{I}\right]$-(3-iodo $\left.\mathrm{Tyr}^{13}\right)-\mathrm{MCH}$, by a factor of 10 (Table 3). $\left[{ }^{125} \mathrm{I}\right]-$ S36057 labelled a similar number of sites in both HEKhMCH-R and CHO-hMCH-R membranes as proven by their similar $\mathrm{B}_{\max }$ (Table 3 ) and as expected from the similar plateau obtained in the dose-dependent protein binding

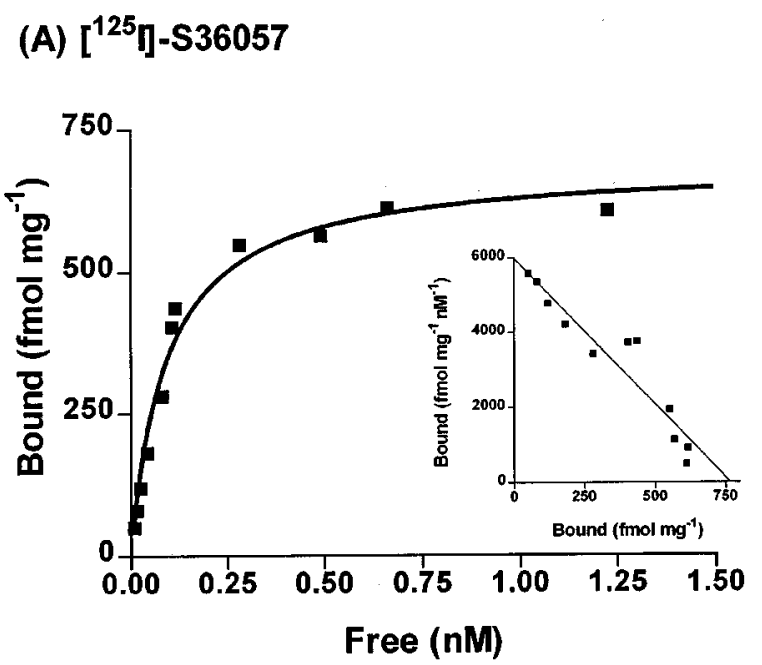

(B) $\left[{ }^{125}\right]-\left(3\right.$-iodo-Tyr $\left.{ }^{13}\right)-\mathrm{MCH}$

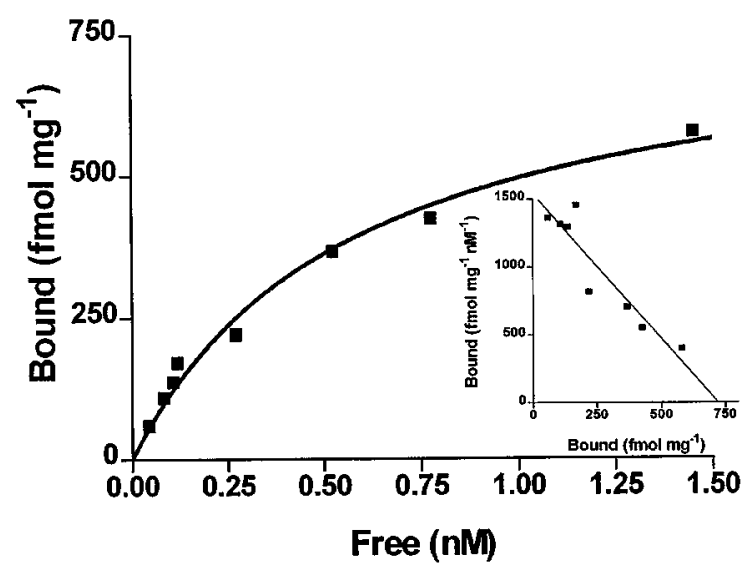

Figure 3 Saturation binding experiments to HEK-hMCH-R membranes. Specific binding is represented. Inset, Scatchard plot of the specific binding. Points shown are from representative experiments performed in triplicates and repeated at least three times. 
Table $3 K_{D}$ and $\mathrm{B}_{\max }$ from saturation analysis of [ $\left.{ }^{125} \mathrm{I}\right]-\mathrm{S} 36057$ and $\left[{ }^{125} \mathrm{I}\right]-\left(3\right.$-iodo-Tyr $\left.{ }^{13}\right)-\mathrm{MCH}$ binding to HEK-hMCH-R and CHOhMCH-R membranes

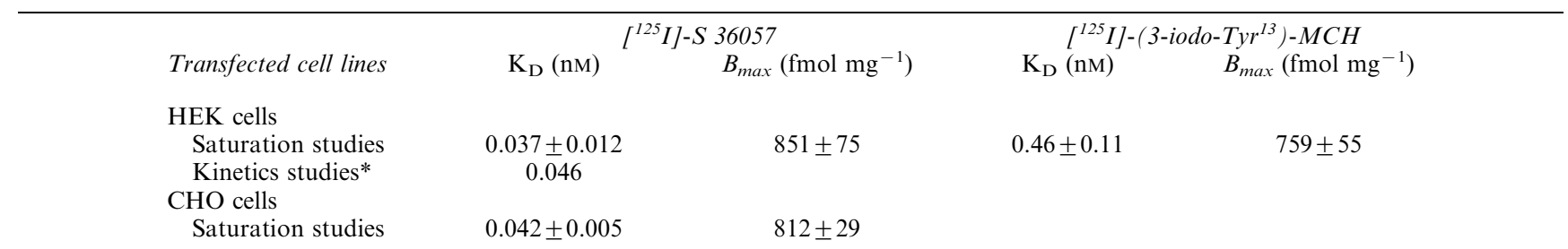

$K_{D}$ (equilibrium dissociation constant) and $\mathrm{B}_{\max }$ (maximal number of binding sites) values were calculated from saturation analysis of $\left[{ }^{125} \mathrm{I}\right]-\mathrm{S} 36057(0.002$ to $1.5 \mathrm{nM})$ and $\left[{ }^{125} \mathrm{I}\right]-\left(3\right.$-iodo-Tyr $\left.{ }^{13}\right)-\mathrm{MCH}(0.02$ to $1.5 \mathrm{~nm})$ binding to HEK-hMCH-R or CHO-hMCH-R membranes. Data represent the mean \pm s.e.mean of at least three separate experiments each performed in triplicate determinations. ${ }^{*} K_{D}$ calculated from the binding kinetics parameters (see Results).

saturation (Figure 2). In both cell lines, the $K_{D}$ values of $\left[{ }^{125} \mathrm{I}\right]-\mathrm{S} 36057$ were similar (Table 3).

\section{Association and dissociation kinetics of $\left[{ }^{125} \mathrm{I}\right]-\mathrm{S} 36057$ binding to HEK-hMCH-R membranes}

Binding association of $\left[{ }^{125} \mathrm{I}\right]-\mathrm{S} 36057$ was achieved in $60 \mathrm{~min}$ and stable for at least $160 \mathrm{~min}$ while dissociation was completely achieved at $3 \mathrm{~h}$ (Figure 4). The $\mathrm{k}_{+1 \text { obs }}$ of association was $0.027 \pm 0.003 \mathrm{~min}^{-1}(n=3)$ and the $\mathrm{k}_{-1}$ for dissociation was $0.018 \pm 0.001 \mathrm{~min}^{-1}(n=2)$. According to the equation $\mathrm{k}_{+1}=\left(\mathrm{k}_{+1 \mathrm{obs}}-\mathrm{k}_{-1}\right) / \mathrm{L}$ where $\mathrm{L}$ is the concentration of radioligand $(0.02 \mathrm{nM}), \mathrm{k}_{+1}$ was equal to $0.39 \mathrm{~min}^{-1} \mathrm{nM}^{-1}$. Calculation of the dissociation constant of $\left[{ }^{125} \mathrm{I}\right]-\mathrm{S} 36057$ as the ratio of $\mathrm{k}_{-1} v s \mathrm{k}_{+1}$ gave a value of $0.046 \mathrm{nM}$ similar to the $K_{D}$ obtained from saturation experiments (Table 3).

\section{Pharmacological characterization of [ ${ }^{125}$ I]-S36057 binding to HEK-hMCH-R membranes}

Inhibition binding isotherms of $\left[{ }^{125} \mathrm{I}\right]-\mathrm{S} 36057(0.02 \mathrm{nM})$ in the presence of $\mathrm{MCH}$ analogues were monophasic (Figure 5A, B). $\mathrm{MCH}$, salmon $\mathrm{MCH}$ and the human analogue $\left[\mathrm{Phe}^{13}\right.$,$\left.\mathrm{Tyr}^{19}\right]-\mathrm{MCH}$ exhibited subnanomolar affinities (Table 4). The fragment $\mathrm{MCH}_{6-17}$ and (3-iodo-Tyr ${ }^{13}$ )-MCH retained potent binding affinity (Figure 5B, Table 4). It is noteworthy that compound $\mathrm{S} 36057$ was the most potent agonist tested (Figure 5B, Table 4). The linear analogue of $\mathrm{MCH}_{6-17}$ obtained by replacement of the two Cys by two Ser residues, compound S36077 (Table 1), led to a compound far less potent than $\mathrm{MCH}_{6-17}$ (Figure 5B, Table 4). The three compounds S36541, S36539 and S36540 (Table 1), also derived from $\mathrm{MCH}_{6-17}$, substituted with non natural amino acids and with the replacement of the cystine bridge by an amide bondpreviously described as $\mathrm{MCH}$ antagonists (Audinot et al., 2001)-showed relatively potent affinities (Figure 5B, Table 4). Similar affinities were obtained using $\left[{ }^{125} \mathrm{I}\right]-\left(3\right.$-iodo $\left.\mathrm{Tyr}^{13}\right)$ $\mathrm{MCH}$ as a radioligand (Table 4), and this was demonstrated by the significant correlation $(r=0.992, P<0.0001, n=10)$ between affinities determined either with $\left[{ }^{125} \mathrm{I}\right]-\mathrm{S} 36057$ or $\left[{ }^{125} \mathrm{I}\right]-$ (3-iodo $\mathrm{Tyr}^{13}$ )-MCH (Figure 6).

\section{$\left[{ }^{125} \mathrm{I}\right]-S 36057$ binding at the rat $\mathrm{MCH}$ receptor}

$\left[{ }^{125} \mathrm{I}\right]-\mathrm{S} 36057$ binding at the rat cloned $\mathrm{MCH}$ receptor expressed in HEK293 cells showed similar binding characteristics (Suply et al., 2001, unpublished results) than those

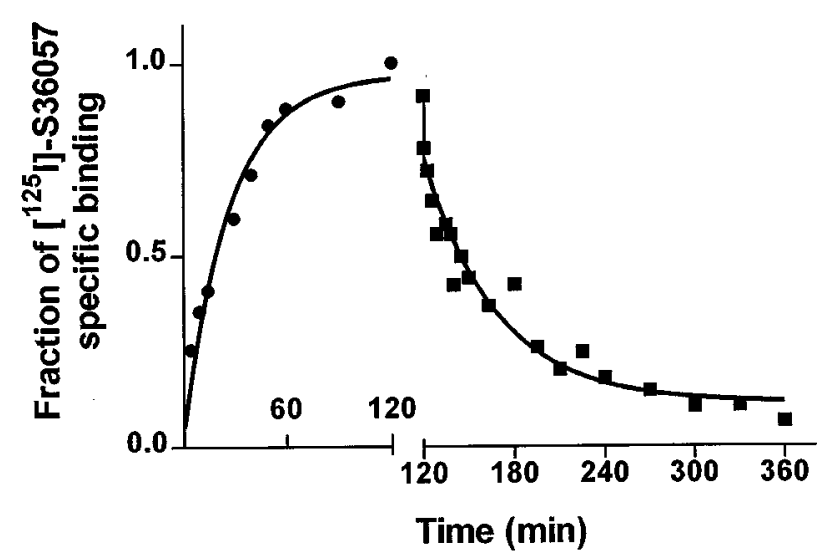

Figure 4 Association (O) and dissociation ( $\mathbf{0}$ ) kinetics of $0.02 \mathrm{~nm}$ $\left[{ }^{125} \mathrm{I}\right]-\mathrm{S} 36057$ specific binding to HEK-hMCH-R membranes. Both association and dissociation were monophasic. The apparent association rate constant $\left(\mathrm{k}_{\text {obs }}\right)$ was $0.027 \pm 0.003 \quad(n=3) \mathrm{min}^{-1}$. Dissociation rate constant was determined after an incubation of $120 \mathrm{~min}$ by the addition of $1 \mu \mathrm{M} \mathrm{MCH}$, giving the dissociation rate constant of $0.018 \pm 0.001 \mathrm{~min}^{-1}(n=2)$. The calculated association rate constant was $0.39 \mathrm{~min}^{-1} \mathrm{nM}^{-1}$ and the derived $K_{D}$ was $0.046 \mathrm{~nm}$. Points shown are from a representative experiment.

obtained with HEK-hMCH-R. In particular, a similar potent dissociation constant was observed $\left(K_{D}=0.029 \pm 0.002 \mathrm{nM}\right.$, $\left.\mathrm{B}_{\max }=1608 \pm 123 \mathrm{fmol} / \mathrm{mg}, n=4\right)$. Binding to rat brain membranes was also performed. Specific binding of $\left[{ }^{125} \mathrm{I}\right]-$ $\mathrm{S} 36057$ and $\left[{ }^{125} \mathrm{I}\right]-\mathrm{MCH}$ only represented $\mathrm{ca} .30 \%$ of total binding. Attempts to reduce the non-specific binding failed to succeed (data not shown). Nevertheless, it was possible to perform [ $\left.{ }^{125} \mathrm{I}\right]-\mathrm{S} 36057$ binding saturation experiments which gave a saturable specific binding (Figure 7). The number of binding sites was $11 \pm 4 \mathrm{fmol} / \mathrm{mg}$ and the dissociation constant was $0.044 \pm 0.007 \mathrm{nM}(n=4)$.

\section{Discussion}

In this study a new highly potent radioligand was described, which mimics the structure and function of $\mathrm{MCH}$ and which could be used for the characterization of $\mathrm{MCH}$ receptors. Starting from the dodecapeptide $\mathrm{MCH}_{6-17}$, which was described as the minimal sequence to retain potent agonistic activity (Audinot et al., 2001), several modifications were performed. Interestingly, the addition of a tyrosine residue at 


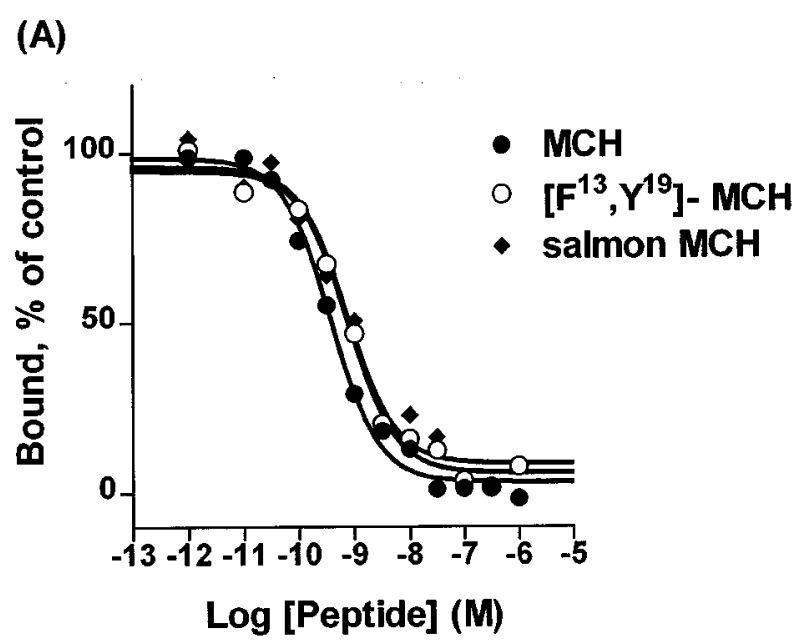

(B)

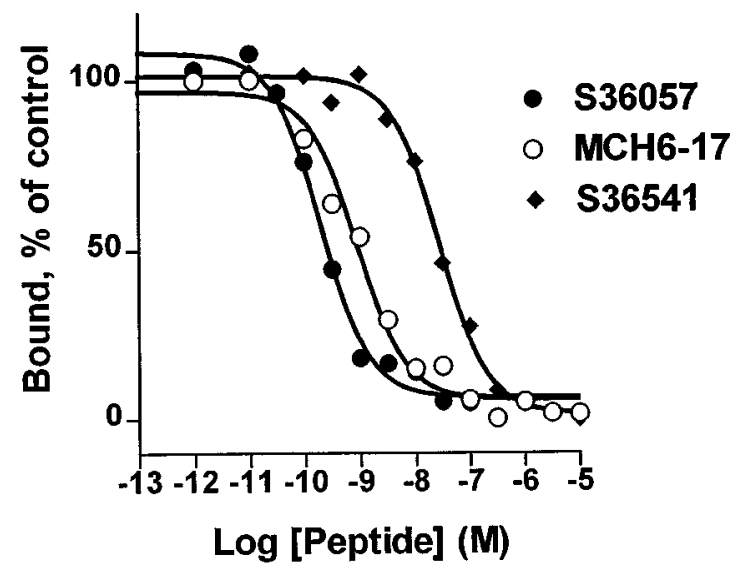

Figure 5 Concentration isotherms of $\left[{ }^{125} \mathrm{I}\right]-\mathrm{S} 36057$ specific binding to HEK-hMCH-R membranes. Points shown are from a representative experiment performed in triplicates and repeated at least three times.

Table 4 Potency of compounds to inhibit [ $\left.{ }^{125} \mathrm{I}\right]-\mathrm{S} 36057$ and $\left[{ }^{125} \mathrm{I}\right]-\left(3\right.$-iodo-Tyr $\left.{ }^{13}\right)-\mathrm{MCH}$ binding to HEK-hMCH-R membranes

\begin{tabular}{|c|c|c|}
\hline \multirow[b]{2}{*}{ Compound } & \multicolumn{2}{|c|}{$\left.\left[{ }^{125} \mathrm{I}\right]-\mathrm{S} 36057{ }^{125} \mathrm{I}\right]-\left(3-\mathrm{iodo}-\mathrm{Ty} \mathrm{r}^{13}\right)-\mathrm{MCH}$} \\
\hline & $\mathrm{K}_{i} \pm$ s.e.mean & $\mathrm{K}_{i} \pm$ s.e.mean \\
\hline \multicolumn{3}{|l|}{ Agonists } \\
\hline S36057 & $0.063 \pm 0.007$ & $0.053 \pm 0.012$ \\
\hline $\mathrm{MCH}$ & $0.164 \pm 0.017$ & $0.109 \pm 0.010$ \\
\hline$\left[\mathrm{F}^{13} \mathrm{Y}^{19}\right]-\mathrm{MCH}$ & $0.382+0.097$ & $0.332+0.150$ \\
\hline $\mathrm{MCH}_{6-17}$ & $0.543 \pm 0.020$ & $0.250 \pm 0.082$ \\
\hline Salmon MCH & $0.353 \pm 0.042$ & $0.282 \pm 0.037$ \\
\hline$\left(3\right.$-iodoTyr $\left.{ }^{13}\right)-\mathrm{MCH}$ & $1.64 \pm 0.36$ & $1.71 \pm 0.74$ \\
\hline S36077 & $155 \pm 43$ & $61 \pm 18$ \\
\hline \multicolumn{3}{|l|}{ Antagonists } \\
\hline S36541 & $13 \pm 1$ & $6 \pm 1$ \\
\hline S36539 & $51 \pm 5$ & $15 \pm 4$ \\
\hline S36540 & $53 \pm 10$ & $22 \pm 6$ \\
\hline
\end{tabular}

$K_{\mathrm{i}}$ (inhibition constant) values from $\left[{ }^{125} \mathrm{I}\right]-\mathrm{S} 36057$ and $\left[{ }^{125} \mathrm{I}\right]$ (3-iodo-Tyr $\left.{ }^{13}\right)-\mathrm{MCH}$ binding experiments. Data are the mean \pm s.e.mean from at least three separate experiments each performed in triplicate determinations.

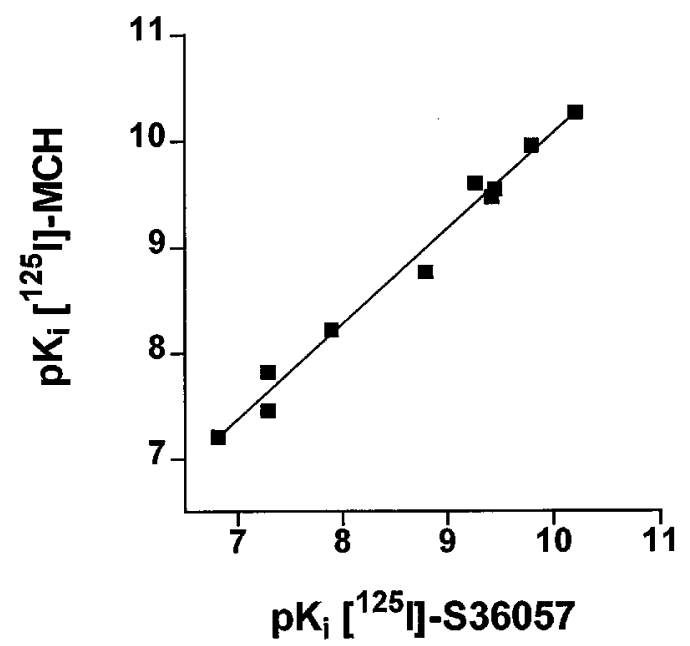

Figure 6 Correlation plot of binding affinities (expressed as $\left.\mathrm{p} K_{\mathrm{i}}=-\log K_{\mathrm{i}}\right)$ determined either with $\left[{ }^{125} \mathrm{I}\right]-\mathrm{S} 36057$ or with $\left[{ }^{125} \mathrm{I}\right]-(3-$ iodo $\left.\mathrm{Tyr}^{13}\right)-\mathrm{MCH}$ at $\mathrm{HEK}-\mathrm{hMCH}-\mathrm{R}$ membranes. Data were calculated from Table 4. The correlation coefficient was 0.992 $(P<0.0001, n=10)$.

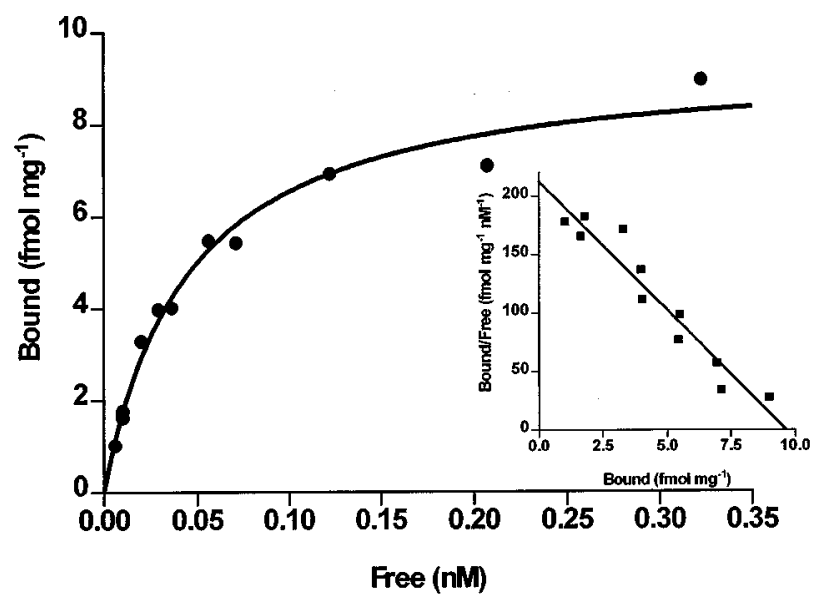

Figure 7 Saturation binding experiments of $\left[{ }^{125} \mathrm{I}\right]-\mathrm{S} 36057$ to rat brain membranes. Specific binding is represented. Inset, Scatchard plot of the specific binding. Points shown are from representative experiments performed in triplicates and repeated four times. In this experiment, the $K_{D}$ and $\mathrm{B}_{\max }$ were respectively $0.045 \mathrm{~nm}$ and $9.6 \mathrm{fmol} \mathrm{mg}^{-1}$.

the N-terminus of $\mathrm{MCH}_{6-17}$ over either the Gly-Gly or the nine-atom linear spacer ADO, even improved its potency as detected through inhibition of cyclic AMP production or $\left[{ }^{35} \mathrm{~S}\right]-\mathrm{GTP} \gamma \mathrm{S}$ binding. Further, neither the iodination of this residue nor the Phe substitution in position 13 were deleterious to agonist activity. Compound S36057, which was chosen for radioiodination, was even more potent than $\mathrm{MCH}$ itself. This new ligand is both shorter and, due to the presence of the ADO spacer, more hydrophilic - and thus less sticky - than MCH. Shortening of fish $\mathrm{MCH}$ has previously been shown to protect against proteolysis as compared to full-length MCH (Checler et al., 1992; Castrucci et al., 1992) as was also the case for S36057. Indeed, $\left[{ }^{125} \mathrm{I}\right]-$ $\mathrm{S} 36057$ was, in our hands, more stable as a radioligand than $\left[{ }^{125} \mathrm{I}\right]$-(3-iodo $\left.\mathrm{Tyr}^{13}\right)-\mathrm{MCH}$. A similar observation was made 
comparing $\left[{ }^{125} \mathrm{I}\right]-\left[\mathrm{Phe}^{13}, 3\right.$-iodo $\left.\mathrm{Tyr}^{19}\right]-\mathrm{MCH}$ and $\left[{ }^{125} \mathrm{I}\right]-(3$-iodo $\mathrm{Tyr}^{13}$ )-MCH (Kokkotou et al., 2000), thus suggesting that iodination of the $\mathrm{Tyr}^{13}$ residue inside the Cys-loop could be deleterious to activity.

The radioligand $\left[{ }^{125} \mathrm{I}\right]-\mathrm{S} 36057$ specifically recognized binding sites on membranes from the HEK293 and CHO cell lines stably transfected with the human $\mathrm{MCH}$ receptor. In contrast and as expected, no specific binding was found in native cells. Similarly, no specific binding of $\left[{ }^{125} \mathrm{I}\right]-\mathrm{S} 36057$ was observed on membranes from the SVK14 cell line. Previous studies in this cell line as well as in others (Burgaud et al., 1997) have reported the existence of a putative $\mathrm{MCH}$ binding site using $\left[{ }^{125} \mathrm{I}\right]$-[Phe ${ }^{13}, 3$-iodo $\left.\mathrm{Tyr}^{19}\right]-\mathrm{MCH}$ as a radioligand. However, these binding sites are not likely to represent the $\mathrm{MCH}$ receptor (at least the SLC-1 form) since: (1) in our experimental binding conditions, which can detect the $\mathrm{MCH}$ receptors specifically expressed in the transfected cell lines, no binding was observed; (2) no messenger mRNA encoding for the $\mathrm{MCH}$ receptor was found in the SVK14 cell line (M. Rodriguez, 2001 unpublished results); and (3) there are strong discrepancies between binding affinities reported in the SVK14 cells and functional activities in transfected cells especially for salmon $\mathrm{MCH}$ and other peptides such as ANF (Burgaud et al., 1997; Chambers et al., 1999, Lembo et al., 1999; Audinot et al., 2001). Moreover, Kokkotou et al. (2000) have recently reported in several cell lines, the existence of a non-specific $\mathrm{MCH}$ binding site which was not associated with the plasma membrane. These particular binding sites thus need to be further characterized.

The two ligands $\left[{ }^{125} \mathrm{I}\right]-\left(3\right.$-iodo $\left.\mathrm{Tyr}^{13}\right)-\mathrm{MCH}$ and $\left[{ }^{125} \mathrm{I}\right]-\mathrm{S} 36057$ recognized a similar number of binding sites on membranes from the HEK-hMCH-R cell line (Table 3). The dissociation constant showed $\left[{ }^{125} \mathrm{I}\right]-\mathrm{S} 36057$ to be 10 fold more potent than $\left[{ }^{125} \mathrm{I}\right]$-(3-iodo $\left.\mathrm{Tyr}^{13}\right)-\mathrm{MCH}\left(K_{D} 0.037\right.$ and $0.46 \mathrm{nM}$, respectively). This highly potent $K_{D}$ for $\left[{ }^{125} \mathrm{I}\right]-\mathrm{S} 36057$ was also confirmed in the $\mathrm{CHO}$ cell line stably expressing a similar number of binding sites than the HEK transfected cell line. In order to confirm the value of the dissociation constant of $\left[{ }^{125} \mathrm{I}\right]-\mathrm{S} 36057$ determined through saturation experiments, the $K_{D}$ was also calculated from the parameters of binding kinetics and a similar value was observed (Table 3). These results confirmed $\left[{ }^{125} \mathrm{I}\right]-\mathrm{S} 36057$ as a 10 fold more potent radioligand than $\left[{ }^{125} \mathrm{I}\right]-\left(3\right.$-iodo $\left.\mathrm{Tyr}^{13}\right)-\mathrm{MCH}$.

S36057 was also more potent than $\mathrm{MCH}$ in competition experiments either using $\left[{ }^{125} \mathrm{I}\right]-\mathrm{S} 36057$ or $\left[{ }^{125} \mathrm{I}\right]$-(3-iodo $\left.\mathrm{Tyr}^{13}\right)$ $\mathrm{MCH}$ as radioligand. For the seven agonist peptides tested, the rank order of binding affinity was comparable with their functional potencies (this study and Audinot et al., 2001). Three potent antagonists also derived from $\mathrm{MCH}_{6-17}$ but extensively substituted with non natural amino acids and with the replacement of the cystine bridge by an amide bond have been reported (Audinot et al., 2001). Significantly these compounds - S36541, S36539 and S36540 - showed potent binding affinities (Figure 5B, Table 4). Therefore, these compounds may represent a useful tool for in vitro studies of $\mathrm{MCH}$ function. For the 10 peptides tested, there was an excellent correlation between the affinities determined with the two radioligands.

Finally, the fact that $\left[{ }^{125} \mathrm{I}\right]-\mathrm{S} 36057$ binding to either HEK cells stably expressing the rat $\mathrm{MCH}$ receptor, or to rat brain membranes gave a potent $K_{D}$, similar to the $K_{D}$ of the human counterpart (as well as a comparable pharmacological profile, Suply et al., 2001, unpublished results), is of importance in view of the high homology of the two species receptors and of the necessary use of rat in both in vivo animal models and autoradiographic studies. In our hands, however, a high level of non-specific binding was observed in rat brain membranes both with [ $\left.{ }^{125} \mathrm{I}\right]-\left(3\right.$-iodo $\left.\mathrm{Tyr}^{13}\right)-\mathrm{MCH}$ and $\left[{ }^{125} \mathrm{I}\right]-\mathrm{S} 36057$. Such a high level of non-specific binding has also been mentionned by Sone et al. (2000) using [ [25 I]-(3-iodo $\left.\mathrm{Tyr}^{13}\right)-\mathrm{MCH}$ in rat brain. This non-specific binding however might be diminished using brain structures enriched in the $\mathrm{MCH}$ receptor (Hervieu et al., 2000).

In conclusion, we have designed, synthesized and used in binding studies $\left[{ }^{125} \mathrm{I}\right]-\mathrm{S} 36057$, a shorter, more potent, more stable and more hydrophilic radioligand than the corresponding $\left[{ }^{125} \mathrm{I}\right]$-(3-iodo $\left.\mathrm{Tyr}^{13}\right)-\mathrm{MCH}$. The availability of both this ligand and the cloned receptor provides $\mathrm{MCH}$ research with a reliable binding assay suitable for testing large numbers of potential $\mathrm{MCH}$ ligands. In addition, the new compound may represent a radioligand of choice for future autoradiographic studies of the $\mathrm{MCH}$ receptor distribution.

\section{References}

AUdinOt, V., BEAUVERGER, P., LAHAYE, C., SUPLY, T., RODRIGUEZ, M., OUVRY, C., LAMAMY, V., IMBERT, J., RIQUE, H., NAHON, J.-L., GALIZZI, J.-P., CANET, E., LEVENS, N., FAUCHERE, J.-L. \& BOUTIN, J.A. (2001). Structure activity studies of MCH-related peptide ligands at SLC-1, the human melaninconcentrating hormone receptor. J. Biol. Chem., in press.

BACHNER, D., KREIENKAMP, H.J., WEISE, C., BUCK, F. \& RICHTER, D. (1999). Identification of melanin concentrating hormone $(\mathrm{MCH})$ as the natural ligand for the orphan somatostatin-like receptor 1 (SLC-1). FEBS Lett., 457, 522 - 524.

BURGAUD, J.L., POOSTI, R., FEHRENTZ, J.A., MARTINEZ, J. \& NAHON, J.L. (1997). Melanin-concentrating hormone binding sites in human SVK14 keratinocytes. Biochem. Biophys. Res. Commun., 241, 622-629.

CASTRUCCI, A.M., VISCONTI, M.A., MATSUNAGA, T.O., HADLEY M.E. \& HRUBY, V.J. (1992). Enzymological studies of melanin concentrating hormone $(\mathrm{MCH})$ and related analogues. Comp. Biochem. Physiol. (B)., 130, 317-320.

CHAMBERS, J., AMES, R.S., BERGSMA, D., MUIR, A., FITZGERALD, L.R., HERVIEU, G., DYTKO, G.M., FOLEY, J.J., MARTIN, J., LIU, W.S., PARK, J., ELLIS, C., GANGULY, S., KONCHAR, S., CLUDERAY, J., LESLIE, R., WILSON, S. \& SARAU, H.M. (1999). Melanin-concentrating hormone is the cognate ligand for the orphan G-protein-coupled receptor SLC-1. Nature, 400, 261 265.

CHECLER, F., DAUCH, P., BARELli, H., NAHON, J.L. \& VINCENT, J.P. (1992). Hydrolysis of rat melanin-concentrating hormone by endopeptidase 24.11 (neutral endopeptidase). Biochem. J., 286, $217-221$.

DROZDZ, R. \& EBERLE, A.N. (1995a). Synthesis and iodination of human (Phenylalanine ${ }^{13}$, Tyrosine ${ }^{19}$ ) melanin-concentrating hormone for radioreceptor assay. J. Pept. Sci., 1, 58-65.

DROZDZ, R. \& EBERLE, A.N. (1995b). Binding sites for melaninconcentrating hormone $(\mathrm{MCH})$ in brain synaptosomes and membranes from peripheral tissues identified with highly tritiated MCH. J. Recept. Signal Transduct. Res., 15, 487-502. 
DROZDZ, R., SIEGRIST, W., BAKER, B.I., CHLUBA-DE TAPIA, J. \& EBERLE, A.N. (1995). Melanin-concentrating hormone binding to mouse melanoma cells in vitro. FEBS Lett., 359, 199-202.

HERVIEU, G.J., CLUDERAY, J.E., HARRISON, D., MEAKIN, J., MAYCOX, P., NASIR, S. \& LESLIE, R.A. (2000). The distribution of the mRNA and protein products of the melanin-concentrating hormone $(\mathrm{MCH})$ receptor gene, slc-1, in the central nervous system of the rat. Eur. J. Neurosci., 12, 1194-1216.

HINTERMANN, E., DROZDZ, R., TANNER, H. \& EBERLE, A.N. (1999). Synthesis and characterization of new radioligands for the mammalian melanin-concentrating hormone $(\mathrm{MCH})$ receptor. J. Recept. Signal Transduct. Res., 19, 411-422.

KAWAUCHI, H., KAWAZOE, I., TSUBOKAWA, M., KISHIDA, M. \& BAKER, B.I. (1983). Characterisation of $\mathrm{MCH}$ in chum salmon pituitaries. Nature, 305, $321-323$.

KOKKOTOU, E., MASTAITIS, J.W., QU, D., HOERSCH, D., SLIEKER, L., BONTER, K., TRITOS, N.A. \& MARATOS-FLIER, E. (2000). Characterization of [Phe13,Tyr19]-MCH analog binding activity to the MCH receptor. Neuropeptides, 34, 240-247.

KOLAKOWSKI, L.F., JUNG, B.P., NGUYEN, T., JOHNSON, M.P., LYNCH, K.R., CHENG, R., HENG, H.H.Q., GEORGE, S.R. \& O'DOWD, B.F. (1996). Characterisation of a human gene related to genes encoding somatostatin receptors. FEBS Lett., 398, 253 258 .

LAKAYE, B., MINET, A., ZORZI, W. \& GRISAR, T. (1998). Cloning of the rat brain cDNA encoding for the SLC-1 G protein coupled receptor reveals the presence of an intron in the gene. Biochim. Biophys. Acta., 1401, 216-220.

LEMBO, P.M., GRAZZINI, E., CAO, J., HUBATSCH, D.A., PELLETIER, M., HOFFERT, C., ST-ONGE, S., POU, C., LABRECQUE, J., GROBLEWSKI, T., O'DONNELL, D., PAYZA, K., AHMAD, S. \& WALKER, P. (1999). The receptor for the orexigenic peptide melanin-concentrating hormone is a G-protein-coupled receptor. Nat. Cell. Biol., 1, 267-271.

PRESSE, F., SOROKOVSKY, I., MAX, J.P., NICOLAIDIS, S. \& NAHON, J.L. (1996). Melanin-concentrating hormone is a potent anorectic peptide regulated by food-deprivation and glucopenia in the rat. Neuroscience, 71, $735-745$.
MACDONALD, D., MURGOLO, N., ZHANG, R., DURKIN, J.P., YAO, X., STRADER, C.D. \& GRAZIANO, M.P. (2000). Molecular characterization of the melanin-concentrating hormone/receptor complex: identification of critical residues involved in binding and activation. Mol. Pharmacol., 58, 217-225.

QU, D., LUDWIG, D.S., GAMMELTOFT, S., PIPER, M., PELlEYMOUNTER, M.A., CULLEN, M.J., FOULDS MATHES, W., PRZYPEK, J., KANAREK, R. \& MARATOS-FLIER, E. (1996). A role for melanin-concentrating hormone in the central regulation of feeding behaviour. Nature, 380, 243-247.

ROSSI, M., CHOI, S.J., O'SHEA, D., MIYOSHI, T., GHATEI, M.A. \& BLOOM, S.R. (1997). MCH acutely stimulates feeding, but chronic administration has no effect on body weight. Endocrinology, 138, $351-355$.

SAITO, Y., NOTHACKER, H.P., WANG, Z., LIN, S.H.S., LESLIE, F. \& CIVELLI, O. (1999). Molecular characterization of the melaninconcentrating-hormone receptor. Nature, 400, 265-269.

SAITO, Y., NOTHACKER, H.P. \& CIVELLI, O. (2000). Melaninconcentrating hormone receptor: an orphan receptor fits the key. Trends Endocrinol. Metab., 11, 299-303.

SHIMADA, M., TRITOS, N.A., LOWELL, B.B., FLIER, J.S. \& MARATOS-FLIER, E. (1998). Mice lacking melanin-concentrating hormone are hypophagic and lean. Nature, 396, 670-674.

SHIMOMURA, Y., MORI, M., SUGO, T., ISHIBASHI, Y., ABE, M., KUROKAWA, T., ONDA, H., NISHIMURA, O., SUMINO, Y. \& FUJINO, M. (1999). Isolation and identification of melaninconcentrating hormone as the endogenous ligand of the SLC-1 receptor. Biochem. Biophys. Res. Commun., 261, 622-626.

SONE, M., TAKAHASHI, K., MURAKAMI, O., TOTSUNE, K., ARIHARA, Z., SATOH, F., SASANO, H., ITO, H. \& MOURI, T. (2000). Binding sites for melanin-concentrating hormone in the human brain. Peptides, 21, $245-250$.

TRITOS, N.A. \& MARATOS-FLIER, E. (1999). Two important systems in energy homeostasis: melanocortins and melanin-concentrating hormone. Neuropeptides, 33, 339-349.

(Received January 11, 2001 Revised March 5, 2001 Accepted March 19, 2001) 